\title{
"Cross-country start-up rates and formal incentives: a moderated mediation model of economic development and societal legitimacy"
}

\begin{tabular}{|c|c|}
\hline AUTHORS & $\begin{array}{l}\text { Colin D. Reddy E https://orcid.org/0000-0002-6657-1071 } \\
\text { R http://www.researcherid.com/rid/F-6977-2019 }\end{array}$ \\
\hline ARTICLE INFO & $\begin{array}{l}\text { Colin D. Reddy (2019). Cross-country start-up rates and formal incentives: a } \\
\text { moderated mediation model of economic development and societal legitimacy. } \\
\text { Problems and Perspectives in Management, 17(1), 297-312. } \\
\text { doi:10.21511/ppm.17(1).2019.26 }\end{array}$ \\
\hline DOI & http://dx.doi.org/10.21511/ppm.17(1).2019.26 \\
\hline RELEASED ON & Monday, 25 March 2019 \\
\hline RECEIVED ON & Saturday, 20 October 2018 \\
\hline \multirow[t]{2}{*}{ ACCEPTED ON } & Friday, 08 February 2019 \\
\hline & $((c)$ EY \\
\hline LICENSE & $\begin{array}{l}\text { This work is licensed under a Creative Commons Attribution } 4.0 \text { International } \\
\text { License }\end{array}$ \\
\hline JOURNAL & "Problems and Perspectives in Management" \\
\hline ISSN PRINT & $1727-7051$ \\
\hline ISSN ONLINE & $1810-5467$ \\
\hline PUBLISHER & LLC "Consulting Publishing Company "Business Perspectives" \\
\hline FOUNDER & LLC "Consulting Publishing Company "Business Perspectives" \\
\hline
\end{tabular}

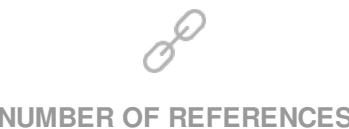

66

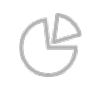

NUMBER OF FIGURES

2

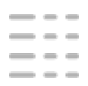

NUMBER OF TABLES

2

(C) The author(s) 2022. This publication is an open access article. 


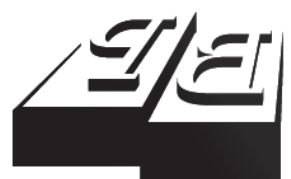

BUSINESS PERSPECTIVES

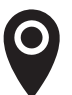

LLC "CPC "Business Perspectives" Hryhorii Skovoroda lane, 10, Sumy, 40022, Ukraine

www.businessperspectives.org

Received on: $20^{\text {th }}$ of October, 2018 Accepted on: $8^{\text {th }}$ of February, 2019

(C) Colin D. Reddy, 2019

Colin D. Reddy, Ph.D., Senior Lecturer of Business Management, Department of Business

Management, Johannesburg Business School, College of Business and Economics, University of Johannesburg, South Africa.

\section{(c) (i)}

This is an Open Access article, distributed under the terms of the Creative Commons Attribution 4.0 International license, which permits unrestricted re-use, distribution, and reproduction in any medium, provided the original work is properly cited.

\section{CROSS-COUNTRY START-UP RATES AND FORMAL INCENTIVES: A MODERATED MEDIATION MODEL OF ECONOMIC DEVELOPMENT AND SOCIETAL LEGITIMACY}

\begin{abstract}
Though current research identifies which institutions are important as boundary conditions for entrepreneurship, questions remain about how they actually influence national entrepreneurial activity, particularly through start-ups. Specifically, the authors attempt to answer the following question: How do formal incentives influence the start-up rates across countries? Through a conceptual framework where formal incentives and societal legitimacy represent formal and informal institutions, respectively, the authors contribute to existing knowledge about national start-up activity by showing both the mechanism and conditions under which formal incentives increase the start-up rate. First, it is argued that formal incentives influence the start-up rate indirectly through the market opportunities available through economic development. Second, it is argued that these formal and informal institutions substitute for one another. The arguments are confirmed with a panel dataset on 57 countries from the World Bank Group Entrepreneurship Surveys and Global Entrepreneurship Monitor. A key implication of the findings is that early efforts at stimulating economic development, for example, by incentivizing foreign investments in new technology, can also kickstart the entrepreneurial activity as much as entrepreneurial activity also contributes to economic development in return.
\end{abstract}

Keywords

JEL Classification start-up, formal incentives, societal legitimacy, economic development, entrepreneurial activity

\section{INTRODUCTION}

Three key contextual factors determine national start-up activity viz. the economic conditions surrounding the opportunities and resources available for entrepreneurs (Porter, Sachs, Jeffrey, \& McArthur, 2002) and the formal and informal institutions that determine its incentive structure (North, 1990; Acs, Desai, \& Hessels, 2008; Acs \& Szerb, 2010; Stenholm, Acs, \& Wuebker, 2011). Institutional theory provides the basis for theoretical arguments demonstrating when the effects of incentives on start-up activity intensify or weaken. Still, these theoretical arguments have yet to extend beyond treating contextual factors as boundary conditions to examining how they influence national entrepreneurial activity, particular in its start-up phase.

Currently, there exists inconsistent empirical support for the role of formal incentives in promoting start-ups (van Stel, Carree, \& Thurik, 2005; Klapper, Laeven, \& Rajan, 2006; Bowen \& De Clercq, 2008; Levie \& Autio, 2008; Stephan \& Uhlaner, 2010). This might be due to 
measurement and multi-collinearity issues (Aidis, Estrin, \& Mickiewicz, 2012). Some argue that formal incentives do not directly have the power to motivate entrepreneurs. They lead to increased competition when other entrepreneurs copy the profitable idea of the first-mover entrepreneur, with the resultant distribution of incentives among many entrepreneurs eventually crowding out and losing its power to motivate entrepreneurs (Shane \& Venkataraman, 2000; Aldrich \& Martinez, 2001). Nevertheless, this remains untested.

We argue that formal incentives do not directly foster start-up activity, they instead first influence the structural changes leading to increased development (De Soto, 2003; Acemoglu \& Johnson, 2005) and a greater opportunity set (Ciccone \& Matsuyama, 1996) to enable start-up activity. In other words, formal incentives operate indirectly by first translating the market opportunities ordinarily available at various stages of economic development to actual start-up opportunities. Essentially, start-up opportunities are those market opportunities with the potential to generate economic value (Shane \& Venkataraman, 2000). Resultant entrepreneurial activity is an outcome of an occupational choice decision (Lucas, 1978; Kihlstrom \& Laffont, 1979) to start a new business (Gartner, 1985). Thus, our research limits entrepreneurial activity to new business start-ups. Finally, we argue that the effectiveness of formal incentives cannot be assessed without due consideration to existing levels of the societal legitimacy for entrepreneurship.

We attempt to answer the following question: How do formal incentives influence national start-up rates? Using longitudinal quantitative procedures, we find that formal incentives influence national start-up activity indirectly through economic development. The role played by formal incentives becomes particularly important under conditions of inadequate societal legitimacy for start-up activity. Formal incentives substitute for this inadequacy.

Our research study contributes to the institutional perspective of entrepreneurship by demonstrating how formal and informal institutions influence national start-up rates. Though we can identify which institutions are important for formal incentives and societal legitimacy, questions remain about how they actually influence markets (Boettke, Coyne, \& Leeson, 2008). In particular, we still require an understanding of how these institutions influence new ventures within these markets (Stenholm et al., 2011).

Institutional variables are often portrayed as conditions for entrepreneurship (Wennekers \& Thurik, 1999). One of the puzzles to solve is the extent to which institutional variables serve as conditions or causes of national level start-up activity. We are inclined to think that societal legitimacy serves as condition or moderating variable, while formal incentives operate more directly to influence the economic situation. Legitimacy issues are deeply embedded in society and are slow to change (Scott, 1994). Formal incentives, on the other hand, operate close to economic activity (Williamson, 2000).

Further, we respond to calls to study the role of the local context in the decision to start a business from both supply-side and demand-side perspectives (Stephan \& Uhlaner, 2010). If either of these supply and demand perspectives is absent, then there is a risk of incomplete understanding of the variations in country-level start-up activity. On the demand side, it is necessary to model the economic situation, which represents the existence of opportunities and resources at the disposal of the potential entrepreneur. This economic situation can be represented by a nation's economic development, which occurs with when a simple, low-income economy grows into a modern, high-income economy (North, 1990). In fact, the Global Competitiveness Report groups countries at the basic level into factor-driven economies, which can develop into efficiency-driven economies and finally into innovation-driven economies (Porter et al., 2002). Because national income levels increase as nations proceed through these levels, economic development has often been proxied by 
relative income or per capita gross domestic product (GDP) (van Stel et al., 2005). Anokhin and Wincent (2012) correlated the log of per capita GDP in constant 1995 US dollars with a binary variable innovation-driven economy and found it to be statistically significant.

Much of national start-up activity results when the entrepreneur, rather than generating them, instead captures profit opportunities from early economic development (Kirzner, 1973). Formal incentives are also an important aspect of the demand side, since they influence the profitability of opportunities and the deployment of resources like financial capital. On the other hand, an important antecedent of the supply-side perspective - the individuals that recognize the incentives and opportunities - includes the societal legitimacy of those individuals' occupational choices.

We first define the abovementioned concepts and articulate a conceptual framework derived from the extant literature. We then go on to empirically test this framework and discuss a theory of an institutional mechanism for national start-up rates. And then we discuss implications for management and suggest further research.

\section{LITERATURE REVIEW}

Previously, researchers found inconsistent support for the direct effect of formal incentives on startup activity (Bowen $\&$ De Clercq, 2008; Klapper et al., 2006; Levie \& Autio, 2008; Stephan \& Uhlaner, 2010; van Stel et al., 2005). For example, both regulatory protection and regulatory complexity had no significant effect on high growth start-up activity (Bowen \& De Clercq, 2008). But when economic development was considered, regulatory complexity had a negative effect on high-growth startups within developing nations and a positive effect within developed nations. This implied a conditional effect of economic development on the formal incentives and start-up activity relationship. In other research, Stephan and Uhlaner (2010) suggest that formal incentives mediate the effect between cultural descriptive norms and start-up activity, confirming the institutional hierarchy argument (Williamson, 2000). In addition, Levie and Autio (2008) tested the effect of formal education institutions on start-up activity and found that this effect is significant only when mediated by the opportunity perception of individuals.

Opportunity perception of individuals when translated to a macro level can be represented by economic development (Shane, 2003). Though start-up activity is known to influence economic development, there is also an overall positive trend in the way start-up rates vary with economic development (Acs \& Szerb, 2009). Among less developed countries, an initial investment in a modern factory that produces 'final goods' will set-off a supply chain of opportunities in the required services and input products for these final goods (Ciccone \& Matsuyama, 1996). This might include activities such as engineering and maintenance work, commerce activities to facilitate transactions, as well as transport and logistic services (Gries \& Naudé, 2009). Possibilities for the possession of idiosyncratic information increase, as the mix of more manufacturing and service activities is added to agricultural activities, since a wider combination of information possibilities and asymmetries arises (Eckhardt, 2003; Grégoire \& Shepherd, 2012).

How do governments sustain such a flurry of economic activity in these economies? They design and implement incentives to attract and retain business and make possible the deployment of resources without any fear of expropriation. Incentives incite individual or organizations to action or greater effort, a reward offered for increased productivity for example. Incentive type problems arise when two parties are present viz. the principal and the agent (Rees, 1985; Eisenhardt, 1989). In market-driven societies, the government serves as the principal party who attempts to achieve its goals through agents like individuals and organizations.

Governments use formal incentives, for example, the property rights that define and help entrepreneurs retain the value they create, to motivate more deployment of resources and to facilitate ex- 
change by reducing transaction costs (Moran \& Ghoshal, 1999). Other formal incentives include less procedures, short times and low costs of starting a business (Djankov, La Porta, Lopez de Silanes, \& Shleifer, 2002), as well as less arduous labor regulations in labor-intensive industries (Klapper et al., 2006). Governments also offer finance at low interest rates, tax abatements for property, and discretionary credits under the government's corporate income tax, low interest financing, social amenities, and public goods like a new road to a factory to attract big business or to incentivize them to continue their operations in the region. Formal incentives may also include the funding of research and development (Bartik, 2005). On the other hand, disincentives can occur when the law does not protect and enforce the contractual rights of entrepreneurs (Moran \& Ghoshal, 1999).

An increase in formal incentives leads to a significant increase in economic development (Rodrik, Subramanian, \& Trebbi, 2004; Xu, 2011). For example, economic development has been traced to enforcement of property rights (Scully, 1988; Acemoglu \& Johnson, 2005; Shleifer, 2009), non-confiscatory taxes and contract enforcement (Scully, 1988; Gwartney, Lawson \& Holcombe, 1999).

Thus far, we have considered the role of the formal institutional environment through its incentive effect on economic development activity. However, formal institutions are guided by the norms and values underlying a society's informal institutions (Thornton et al., 2011). At the macro-level, outcomes like entrepreneurial activity through startups are as much a result of government incentives as they are of the society (Rodrik et al., 2002; Hausmann \& Rodrik, 2003).

Societal legitimacy for entrepreneurship develops when some groups in society deem starting a business to be socially acceptable or consistent with their norms, values, and beliefs (Jepperson, 1991). Society confers legitimacy - "a generalized perception or assumption that the actions of an entity are desirable, proper, or appropriate within some socially constructed system of norms, values, beliefs, and definitions" (Suchman, 1995, p. 574) - to economy activity. Legitimacy can be sought pragmatically through responding to societal self-interest, morally through obeying certain approved norms and cognitively through applying taken for granted methods. Whereas cognitive legitimacy derives from widely shared social knowledge, moral legitimacy derives from the values of society, which indicates the extent to which its people admire entrepreneurial activities such as creativity and innovation. In a more pragmatic form of legitimacy, society supports start-up activity for its material gain. Society may also recognize the autonomy of the businesses involved in these activities. Unlike pragmatic legitimacy, moral legitimacy rests not on an evaluation of the benefits to society, but on whether entrepreneurship is the 'right thing to do'. On the other hand, cognitive legitimacy rests not on any form of evaluation, but on a taken-for-grantedness (Suchman, 1995). Using societal legitimacy to represent this societal environment, we could argue that it moderates the indirect effect of formal incentives on entrepreneurial activity through start-ups.

\section{HYPOTHESES}

The notion that opportunity perception serves as a mediator between institutional forces and start-up activity (Levie \& Autio, 2008) is appealing. By viewing economic development as a macro level proxy for the availability of start-up opportunities, we could be able to translate Levie and Autio's (2008) finding to a macro perspective. This will enable us to examine how both institutions and economic development influences national start-up rates. We delineate the incentive structure of institutions into formal incentives like tax and antitrust policies and societal legitimacy type incentives like the admiration of entrepreneurs. Whereas judges, legislators and bureaucrats may change, enact or enforce formal incentives (North, 1990), society uses 'rules in operation' rather than just 'rules in force' (Ostrom, 2009). Legitimacy issues, in particular, become crucial when considering broader samples including developing countries and those with diverse cultural backgrounds (Liñán \& Chen, 2009; Iakovleva, Kolvereid, \& Stephan, 2011). That societal legitimacy is important can also be observed from the evidence that the same formal incentives imposed on different societies produce different outcomes (Jütting, 2003). This might be due to significant stakeholder groups who hold notions of what is legitimate 


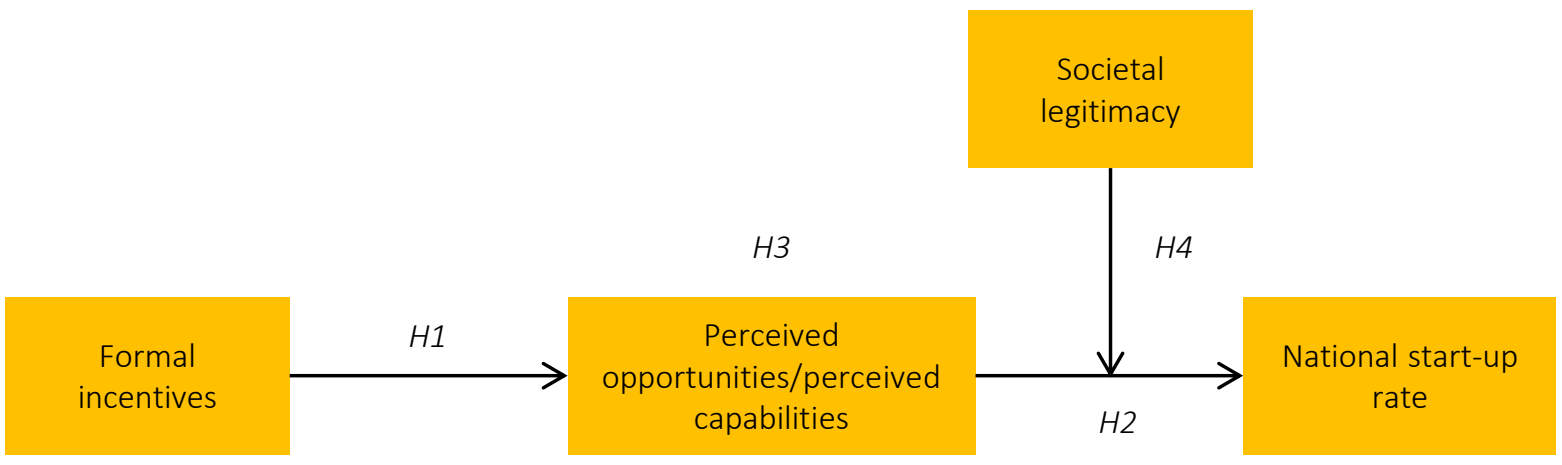

Figure 1. Conceptual framework

arising from their own norms, values, and beliefs that conflict with the outcomes being targeted by formal incentives (Safran, 2003; Webb, Tihanyi, Ireland, \& Sirmon, 2009). Specifically, we attempt to answer the following question: How do formal incentives influence national start-up rates? Our solution is depicted in Figure 1.

On the way to economic development, countries compete for labor, capital and economic activity by offering formal incentives to firms wishing to invest in them (Weingast, 1995). Formal incentives are particularly important to secure the capital resources required for economic development (De Soto, 2003). Securing the best resources is a primary economic problem confronting those countries aspiring towards increasing economic development (Moran \& Ghoshal, 1999). Formal incentives, particularly in the form of market-oriented regulations, become necessary for economic development when it becomes increasingly complex to transact (Acs et al., 2008a; Acs \& Virgill, 2010). For instance, when the economic structure advances through innovation, intellectual property laws ensure that the enterprise or individuals owning the innovation will be protected from unsavory parties involved in potential market transactions. Under these circumstances, innovators and resource providers become confident that they can appropriate the value attached to their efforts (Autio \& Acs, 2010). We thus hypothesize that:

\section{H1: An increase in formal incentives leads to an increase in economic development.}

Though technological changes has dominated the discussion of how changes in economic structure (Solow, 1957; Blau, 1987; Porter et al., 2002; Acs \&
Armington, 2004) give rise to opportunities, social and demographic changes also accompany a country's economic development (Porter et al., 2002). These include the changes in consumer demand (Reynolds, Storey, \& Westhead, 1994; Audretsch \& Keilbach, 2004) due to high disposable incomes. Consumer needs for variety occur when people in more developed nations experience greater desires for self-realization; and such needs can be met when income levels increase (Jackson, 1984), making the introduction of new products less risky. Collectively, these changes from economic development will give rise to abundant opportunity for individuals to start businesses. Therefore, we hypothesize that:

\section{H2: An increase in economic development leads to an increase in start-up rates.}

We observe from hypotheses 1 and 2 above that formal incentives influence the economic development and economic development in turn influences the start-up rate. Economic development plays a mediating role between formal incentives and the start-up rate. This is in line with arguments that economic development results from the adoption of particular institutions and not entrepreneurship, which is an "omnipresent aspect of human action” (Boettke \& Coyne, 2003, p. 67).

Formal incentives turn ordinary opportunities to profit opportunities - the kind of opportunities that attracts entrepreneurs. This means that formal incentives are unlikely to influence startup rates without the presence of opportunities to start businesses. This is where economic development plays an important role. Much of national start-up activity results when the entrepreneur 
rather than generating them instead captures profit opportunities from the technological development accompanying early economic development (Kirzner, 1973). Potential entrepreneurs then recognize these opportunities from changes in technology to produce variants of services and inputs to large manufacturing enterprises (Ciccone \& Matsuyama, 1996). These include the opportunities to start manufacturing and service type businesses within the supply chains of the pioneer businesses. Moreover, potential entrepreneurs also use the wealth from increases in per capita income to access resources to exploit opportunities. Wealth also brings with it desires for the products and services (Jackson, 1984). We argue that:

\section{H3: The effect of formal incentives on start-up rates is fully mediated by its effect on eco- nomic development.}

Both formal and informal institutions form the incentive structure for economic activity (North, 1990). When one is not present, we expect the other to compensate for it. Therefore, we expect the indirect effect of formal incentives to be more important at low levels of societal legitimacy. In particular, the indirect effect of formal incentives on national start-up activity occurs through economic development with its increasing availability of resources and opportunities for start-up activity. In an ambiguous incentive context, potential entrepreneurs will evaluate these opportunities on social cues (Aldrich, 1999; Kwon \& Arenius, 2010). In particular, the societal legitimacy of start-up activity influences the perceptions of these opportunities (Welter \& Smallbone, 2003). An overall effect results where societal legitimacy moderates the relationship between economic development and start-up activity (Busenitz, Gomez, \& Spencer, 2000; Hayton et al., 2002). Potential entrepreneurs in a low legitimacy context will struggle to access the increase in resources available. In these situations, the role of formal incentives becomes important and works to compensate for the low levels of societal legitimacy. On the other hand, nations need not rely on wholly formal incentives when high levels of societal legitimacy for start-up activity are present. Under these circumstances, society views entrepreneurs with pride and this seems adequate to spur on individuals to make use of the increase in resources available from economic development. Such societies can easily overcome some of the apparent disincentives from formal government policies and regulations, since members of such a society recognize and value the opportunities for individual freedom through owning and operating their own business. We suggest:

\section{H4: Societal legitimacy moderates the indirect effect of formal incentives on start-up rates such that this indirect effect decreases at high levels of societal legitimacy.}

It is noteworthy that we do not hypothesize the direct effect of either formal incentives and societal legitimacy or their interaction on start-up activity. This is in accord with our theory that they are but conditions for start-up activity.

\section{METHOD}

\subsection{Data collection}

We used the Global Entrepreneurship Monitor (GEM) and World Bank Group Entrepreneurship Surveys (WBGES) and the International Monetary Fund (IMF) database to construct a country-level panel dataset for up to 57 countries over the period from 2000 to 2009. This resulted in a dataset of 238 country-year observations comprising 155 developed country-year and 83 developing country-year observations. Because we used lagged values in our regressions, country-year observations dropped to 155 in some of our models.

The WBGES tallies new business registrations across the world, limiting the application of this research to formal economic activity (Klapper \& Delgado, 2007; Acs et al., 2008b). Entrepreneurs who are motivated by an opportunity to grow their business also tend to register their enterprises (Levie \& Autio, 2011). While GEM data measure the potential for start-up activity, the World Bank data measure actual start-up activity, albeit at a formal level in terms of registered start-ups (Acs et al., 2008b).

To operationalize economic development, we rely on per capita GDP data based in US dollars, available from the IMF. To assess a country's formal incentives or societal legitimacy, we rely on GEM's 
national expert survey. Individuals with knowledge about their economies are probed about the entrepreneurial framework conditions (EFC) in their country. GEM uses standardized questions and validated measurement scales about these EFCs (De Clercq, Lim, \& Oh, 2011). The panel of experts must include a supplier, an academic with knowledge about the country's entrepreneurship challenges, as well as an entrepreneur. Country aggregate scores for each EFC derive from the mean of the 36 expert responses per country.

The EFCs measured conditions for start-up activity such as financial support, policy and regulatory conditions, the business content of primary and higher education, business services, market conditions, $\mathrm{R} \& \mathrm{D}$ conditions, general entrepreneurial capability, entrepreneurial culture and entrepreneurial image. The responses were collected on a five-point Likert scale. The five-point Likert scale comprised of completely false (1), Somewhat false (2), neither true nor false (3), somewhat true, (4) or completely true (5). It weighted the multi-item scale on the factor loadings of individual scale items.

\section{MEASURES}

\section{Start-up activity}

This is based on entry density, which is defined as the number of newly registered limited liability companies per 1,000 working-age people, aged 15-64 years old (Klapper \& Delgado, 2007). The WBGES uses official business registers to provide cross-national data on the number of newly registered businesses (Acs et al., 2008b).

\section{Economic development}

It has been recognized that economic development results in increasing per capita income (van Stel et al., 2005; S. Wennekers, A. Wennekers, Thurik, $\&$ Reynolds, 2005). We use natural log transformations of gross domestic product per capita data from the IMF database. To obviate concerns about reverse causality from start-up activity to economic development, the lagged value of income per capita is used. A lagged value of income per capita also accounts for the time taken for entre- preneurs to identify and then exploit the opportunities arising out of any technology changes from a country's efforts at economic development.

\section{Formal incentives}

We formed a multi-item scale with items from the GEM policy and regulations EFC and the market openness EFC. The resultant 11-item scale's Cronbach alpha was 0.91 . The policy and regulations EFC comprises seven items probing expert opinions ranging from policy support for start-up activity to opinions on the response time when applying for permits and licences, the tax burden, the predictability of regulations and coping whether new businesses cope with regulations. The market openness EFC comprises four items including the ease of entry into new markets, the cost of market entry, being blocked by established firms and the effectiveness of competition legislation. Our measure thus extended beyond considering the quality of policies regulations around taxes and licences to consider also the facilitation of market entry.

\section{Societal legitimacy}

We developed a scale combining all three forms of legitimacy viz. pragmatic, moral and cognitive (Suchman, 1995). We used the entrepreneurial culture, entrepreneurial social image, and entrepreneurial capacity EFCs to proxy pragmatic, moral, and cognitive legitimacies, respectively. Our resultant 15-item scale's Cronbach alpha was 0.93. The entrepreneurial culture EFC comprises five items probing whether national culture supports individual success, emphasizes self-sufficiency, encourages risk-taking, encourages creativity and emphasizes individual responsibility. The entrepreneurial social image EFC comprises five items probing entrepreneurship as an appropriate way to become rich, a desirable career choice, attracting a high level of status and respect, media attention and thoughts of entrepreneurs as competent and resourceful individuals. The entrepreneurial capacity EFC comprises five items probing whether people know how to start and manage a small business, start and manage a high-growth business, are experienced in starting a new business, have the ability to mobilize resources and can react quickly to good opportunities for a new business. 


\subsection{Control variables}

We included several controls to increase the robustness of our models. We controlled for the population of nation, which can reflect the potential for market demand (Levie \& Autio, 2011). Structural changes in an economy - increasing its market orientation - can give rise to startup opportunities (Bowen \& de Clercq, 2008). To control for this, we used a dummy variable indicating whether a country is a transition economy, defined as one that has transitioned from a centrally planned economy to a market-oriented economy. In our dataset, these included Bosnia and Herzegovina, Croatia, Czech Republic, Hungary, Latvia, Macedonia, Poland, Romania, Russia, Serbia, and Slovenia. The dominance of incumbents may alter the opportunity landscape for new entrants. Following the practice of Levie and Autio (2011), we include a measure of industry structure. Like them, we controlled for industry structure by using GEM's index of established entrepreneurship in the country.

Foreign direct investment (FDI) can increase the financial access to entrepreneurs (De Backer \& Sleuwaegen, 2003; Ayyagari \& Kosová, 2010). We therefore control for FDI as a percent of a nation's GDP. We also included time fixed effects to account for unobserved characteristics across years that might arise from missing variables (Wooldridge, 2002). These time dummies might control for sporadic events like the global financial crisis. Some of these control variables, for example, FDI as a percent of GDP, and our main institutional variables have an influence on economic development. Bringing these variables into the model also obviates the endogeneity of our economic development variable. In addition, since the full model is often more robust, we use our explanatory variables as controls when necessary.

\subsection{Statistical procedures}

We framed our analysis around the moderated mediation model (Muller, Judd, \& Yzerbyt, 2005), implied by our hypotheses. Moderated mediation occurs when a mediating effect is moderated by some variable (Baron \& Kenny, 1986).
We first developed the mediation model Accordingly, we modelled the effect of formal incentives on economic development. We modelled the effect of economic development on start-up activity. This latter model included all the controls, as well as our institutional variables - formal incentives and societal legitimacy. We used this model to not only test hypothesis 2 - the main effect of economic development on start-up activity - but also to check if a nation's formal incentives are significantly related to start-up activity when modelled together with economic development. To test for mediation, we need to develop models with and without the effect of the mediator variable (Baron \& Kenny, 1986). Accordingly, in a subsequent model, we removed the effect of economic development so that we can examine any change in the significance of formal incentives on start-up activity. Finally, we included the interaction effect of societal legitimacy and economic development to test a second stage moderation model. To examine the nature of the effect of societal legitimacy on the overall mediation model, we used an equation specified by Edwards and Lambert (2007) for second stage moderation. This equation enables one to calculate the simple slopes (Dawson \& Richter, 2006) for a second stage moderated mediation model.

For the full moderated mediation model, we examined the sign of the interaction term. When the main effect terms have opposite signs, it indicates that one variable buffers or weakens the effect of the other. When they have the same sign, then a complementary or enhancing interaction is likely. When both main effects have the same sign, but the higher order interaction term contains a different sign (Neter et al., 1996), then there is a compensating effect (J. Cohen, P. Cohen, West, \& Aiken, 2003).

We applied panel regression analysis to our data. The dataset was unbalanced, because a few countries did not participate in the survey for all years. Baltagi-Wu test values much smaller than 2 are suggestive of the need to correct for serial autocorrelation (see Levie \& Autio, 2008). We obtained a test value of 1.8 and we therefore ran generalized least squares (GLS) models without controlling for autocorrelation in error terms. 


\section{RESULTS}

Table 1 presents the descriptive and summary statistics for our measures. Because we use actual GDP per capita values together with scales to measure formal incentives and societal legitimacy, we standardize our values for use in the regression models. This procedure also helps with multicollinearity, particularly since we include interaction variables. However, our VIF values were less than 3; values above 10 indicate a severe problem (Hair et al., 1995). For a relatively small sample, like ours is, and particularly where $t$ values are low, VIF values well below 5 are appropriate (O’Brien, 2007; Allison, 2012).

We applied a random effects specification to our models. This works well for this unbalanced data set, because random effects use partial pooling and a shrinkage estimator, which pushes extreme values towards the mean (Wooldridge, 2002). In addition, random effects use both changes over time and between country effects to arrive at an estimate. However, fixed effects are useful to mitigate against any omitted variable bias. We therefore ran our full model with the fixed effects specification and arrived at similar results. We also selected robust standard errors to mitigate against heteroscedasticity.

Hypothesis 1 proposed a positive correlation between the formal incentives and economic development. This hypothesis was necessary to evaluate stage one of the moderated mediation model, which indicates that the main explanatory variable formal incentives are indeed related to the mediating variable economic development. As shown in model 1 of Table 2, the relationship between formal incentives and economic development $(b=0.228, p<0.01)$ is significant, which lends support to hypothesis 1 .

Table 1. Descriptive statistics and correlations (for unstandardized values)

\begin{tabular}{l|c|c|c|c|c|c|c|c}
\hline \multicolumn{1}{c}{ Measures } & Mean & S.D. & $\mathbf{1}$ & $\mathbf{2}$ & $\mathbf{3}$ & $\mathbf{4}$ & $\mathbf{5}$ & $\mathbf{6}$ \\
\hline 1. Start-up rate & 4.181 & 4.025 & - & - & - & - \\
2. Per capita GDP log & 4.205 & 0.448 & $0.410^{*}$ & - & - & - \\
3. Established business activity & 6.548 & 3.666 & -0.019 & $-0.318^{*}$ & - & - \\
4. FDI per GDP & 5.464 & 8.829 & $0.172^{*}$ & 0.103 & $-0.175^{*}$ & - \\
5. Population (million) & 30.253 & 77.626 & $-0.200^{*}$ & $-0.466^{*}$ & 0.102 & -0.115 & - \\
6. Formal incentives & 2.555 & 0.412 & $0.471^{*}$ & 0.094 & $0.151^{*}$ & $0.137^{*}$ & 0.12 \\
7. Societal legitimacy & 2.882 & 0.338 & $0.469^{*}$ & $0.537^{*}$ & -0.120 & $0.167^{*}$ & $-0.185^{*}$ & $0.491^{*}$ \\
\hline
\end{tabular}

Note: $n=238,{ }^{*} p<.05$.

Table 2. Regression results

\begin{tabular}{|c|c|c|c|c|}
\hline \multirow[t]{2}{*}{ Models } & First stage & Second stage & Mediation test & $\begin{array}{c}\text { Moderated } \\
\text { mediation }\end{array}$ \\
\hline & Model 1 & Model 2 & Model 3 & Model 4 \\
\hline Dependent variable & $\begin{array}{c}\text { Economic } \\
\text { development }\end{array}$ & Start-up rate & Start-up rate & Start-up rate \\
\hline Population & $-0.150^{* *}$ & -0.079 & $-0.148^{* *}$ & -0.071 \\
\hline Transition economy dummy & $-0.730^{* * *}$ & 0.137 & 0.007 & 0.230 \\
\hline Established business activity & $-0.081 *$ & -0.026 & -0.078 & -0.018 \\
\hline Foreign direct investment per GDP & -0.035 & 0.135 & .0 .099 & 0.132 \\
\hline Societal legitimacy & 0.019 & $0.184 * *$ & $0.151 *$ & $0.215^{* *}$ \\
\hline Formal incentives & $0.228 * *$ & 0.081 & $0.169 *$ & 0.078 \\
\hline Economic development (lagged) & $-\ldots$ & $0.314 * *$ & $-\ldots$ & $0.369^{* *}$ \\
\hline $\begin{array}{l}\text { Economic development } x \text { societal } \\
\text { legitimacy }\end{array}$ & - & - & - & $-0.079 *$ \\
\hline Constant & $-0.769 * * *$ & -0.088 & $-0.530^{* * *}$ & -0.070 \\
\hline Observations & 238 & 155 & 238 & 155 \\
\hline Groups & 57 & 38 & 57 & 38 \\
\hline Adjusted R-square & 0.945 & 0.918 & 0.884 & 0.918 \\
\hline Chi-Square statistic & $189.72 * * *$ & $125.18^{* * *}$ & $68.37 * * *$ & $89.75^{* * *}$ \\
\hline Log likelihood & -96.835 & -87.714 & -160.228 & -86.876 \\
\hline AIC & 231.671 & 211.427 & 356.455 & 211.427 \\
\hline
\end{tabular}

Note: ${ }^{*} p<0.05,{ }^{* *} p<0.01,{ }^{* *} p<0.001$, year effects controlled for, but not shown, observations reduce when lagged variable for economic development is used. 
Hypothesis 2 proposed a positive correlation between the economic development and start-up activity. Model 2 of Table 2 shows that this relationship $(b=0.314, p<0.01)$ is significant. This result lends support to hypothesis 2 .

Hypothesis 3 proposed that the effect of formal incentives on start-up activity is fully mediated by its effect on economic development. Hypotheses 1 and 2 go some way in confirming the mediating effect of economic development, but scholars (Baron \& Kenny, 1986) have advised to confirm this by developing models with and without the effect of the mediator variable. Model 2 shows the effect of formal incentives on start-up activity with economic development. The effect $(b=0.081, p>0.05)$ is not significant. However, when economic development is excluded in model 3 , the effect of formal incentives $(b=0.169, p<0.05)$ becomes significant. This lends support to our hypothesis that economic development mediates the relationship between formal incentives and start-up activity.

Hypothesis 4 proposed that societal legitimacy moderates the indirect effect of formal incentives on start-up activity such that this indirect effect decreases at high levels of societal legitimacy. Model 4 shows that the interaction between societal legitimacy and economic development $(b=-0.079, p<.05)$ is negative and significant. We can thus proceed to investigate the nature of this interaction.

In the case of a moderated mediation model, main effects refer to the indirect effect of formal incentives and the effect of societal legitimacy. Both main effects have the same positive sign, but the higher order interaction term contains a negative sign. This confirms a compensating effect between societal legitimacy and the indirect effect of formal incentives on start-up activity. We go further to interpret the moderating effect in terms of the entire mediating model, i.e. the indirect effect of formal incentives on start-up activity. We use Edwards and Lambert's (2007) slope equation, choosing respective coefficient together with low and high value combinations of formal incentives and societal legitimacy and we arrive at the simple slopes depicted in Figure 2. When we observe the simple slopes, we note that at high levels of societal legitimacy, the indirect effect of formal incentives is lower than at low levels of societal legitimacy. This lends support to hypothesis 4 .

For robustness, we applied a fixed effects specification to our full model. This model caters for possible omitted variables by inserting all the country effects. We arrive at the same patterns. In addition, we delineated the formal incentives measure into separate government regulations and market openness dimensions and we tested these separately in our models. Notably, market openness appears to play a stronger role than government regulations in our models. The market openness measure comprises four items including the ease of entry into new markets, the cost of market entry, being blocked by established firms and the effectiveness of competition legislation.

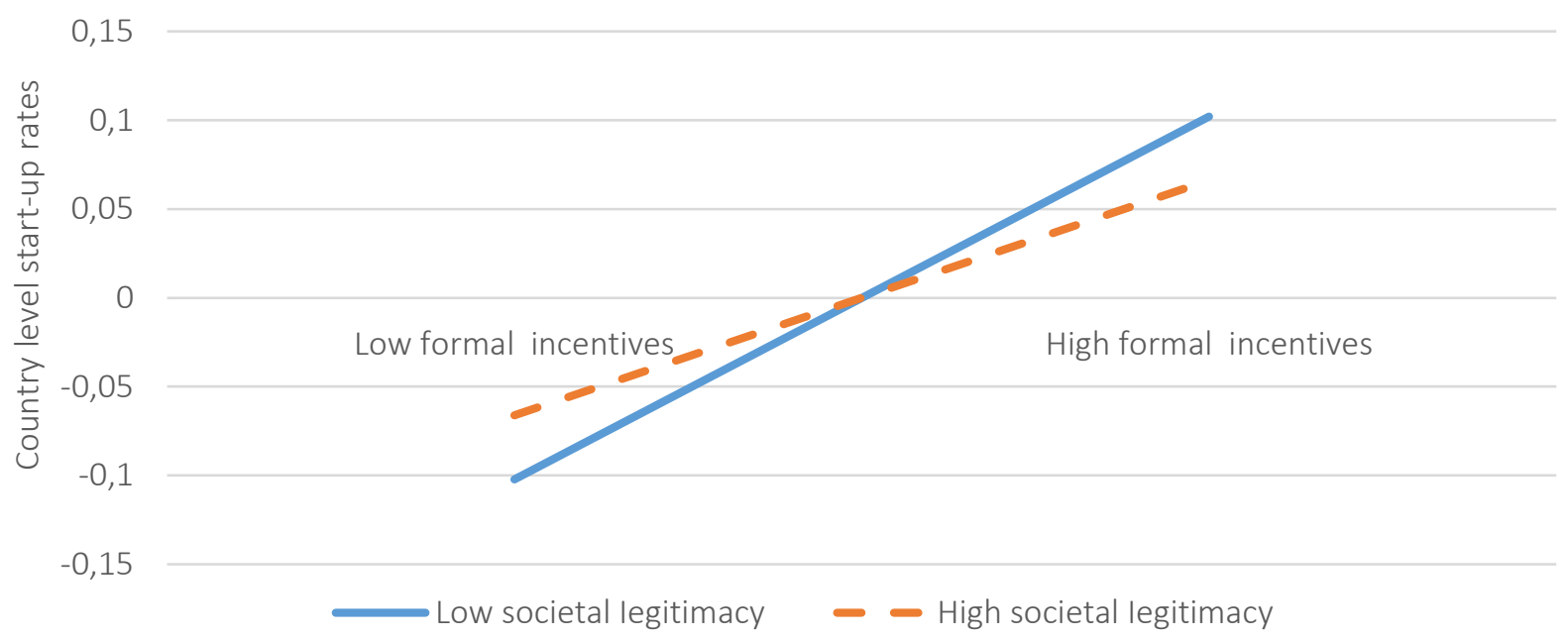

Figure 2. Simple slope results 


\section{DISCUSSION}

We set about examining how formal incentives influence national start-up activity. We found that formal incentives have an indirect and positive effect on start-up activity. Increases in formal incentives first lead to an increase in economic development. The abundance of opportunities and resources in this economic developed environment together with the stronger incentives for entrepreneurship then lead to an increase in startup activity. We also find that this indirect effect of formal incentives is more important when levels of societal legitimacy for entrepreneurship are low.

\subsection{The indirect effect of formal incentives on start-up activity}

The findings of the present research suggest that formal incentives, especially government's efforts at maintaining open markets and implementing effective competition legislation are positively related to start-up activity, albeit through an indirect process. As noted earlier, there are strong grounds for predicting such a relationship. Intuitively, the mere existence of opportunities and resources cannot translate to start-up activity without formal incentives to enhance their profitable application and to spur the potential entrepreneur into action (Etzioni, 1987; Hayton et al., 2002; Thornton et al., 2011). Moreover, formal incentives cannot influence start-up activity in isolation. Opportunities and resources are important to complement the design of formal incentives for start-up activity. We argued that differences in economic development represent the variations in these opportunities and resources.

As a result, formal incentives first stimulate the beginnings of the transition to higher levels of economic development before impacting on start-up activity. This might happen by incentivizing foreign investments in new technology (Ozawa, 1992; Young, Hood, \& Peters, 1994). Formal incentives, particularly in the form of market-oriented regulations, become necessary for economic development when it becomes increasingly complex to transact (Acs et al., 2008a; Acs \& Virgill, 2010). For instance, when the economic structure advances through innovation, intellectual property laws ensure that the foreign enterprise owning the in- novation will be protected from unsavory parties involved in potential market transactions. Under these circumstances, foreign investors become confident that they can appropriate the value attached to their efforts (Autio \& Acs, 2010).

Much of national start-up activity results when the entrepreneur rather than generating them instead captures profit opportunities from the technological development accompanying early economic development (Kirzner, 1973). Potential entrepreneurs then recognize these opportunities from changes in technology to produce variants of services and inputs to large manufacturing enterprises (Ciccone \& Matsuyama, 1996). These include the opportunities to start manufacturing and service type businesses within the supply chains of the pioneer businesses. Formal incentives help turn these initially ordinary opportunities to profit opportunities - the kind of opportunities that attract entrepreneurs. Of course, once start-up activity increases during the transitory stage of economic development, it begins to also play a role in increasing the momentum towards economic development.

Our findings integrate past research. We confirm Levie and Autio's (2008) arguments that opportunity perception serves to mediate between formal type institutions and start-up activity. Our use of longitudinal data allows us to use differences and changes in economic development to proxy the differences and changes in opportunity perceptions that might occur across and within countries.

\subsection{The moderating effect of societal legitimacy}

We also confirm Stephan and Uhlaner's (2010) argument that the cultural norms that lend legitimacy to start-up activity are of a higher order than formal incentives. We however argue that it serves as a condition on the indirect effect of formal incentives on start-up activity and not as a primary explanatory variable of national start-up activity.

Suppliers of resources readily support entrepreneurs when start-up activity is viewed as legitimate, which increases start-up rates (Etzioni, 1987). When legitimacy is not present, information asymmetries occur, which then leads to dif- 
ficulty in accessing resources and even thwarting the start of businesses (Spencer et al., 2005). Aside from resources providers, the society surrounding the potential entrepreneur also includes customers, suppliers, and other stakeholders such as legislators - a collective also important to turn start-up activity into a successful outcome.

We found that the indirect effect of formal incentives on national start-up activity becomes pronounced when the levels of societal legitimacy for start-up activity is particularly low. This makes sense when we consider North's (1990) argument that both formal and informal institutions serve as the incentive structure for economic activity. This incentive structure is held in place when informal and formal institutions can compensate for one another. In other words, they substitute for each other.

There has been research that alludes to a multiplicative or enhancing effect where such formal and informal institutions serve complements of each other. Meek, Pacheco, and York (2010) suggest that government-sponsored incentives are more effective at promoting start-up activity in the solar energy sector when surrounded by or greater levels of family interdependence or greater individual freedom. Future research can look at whether decomposing formal and informal institutions into individual components results in different interaction behavior compared to when considering each institution as a whole.

\subsection{Practical implications}

Reformers wishing to increase the rates of startup activity within their societies must understand the current rule structure from both an incentive and a legitimacy perspective. We have shown that it is particularly important for governments of societies where start-up activity enjoys low levels of legitimacy to design strong formal incentives.

The mental models of potential entrepreneurs, various state officials, and resources providers shape the choices they make. When these mental models regard start-up activity as legitimate, they can then stimulate start-up activity despite the presence of relatively weak levels of formal incentives. Potential entrepreneurs still perceive support from resource providers and resultant lower transaction costs providing a substitute incentive for them to start a business.

Among less developed countries, as investments take place in upgrading existing technology and even moving into new technology, opportunities for start-up activity increase. This increase in resources both technological, financial and the potential for skills transfer from investors might lead to an increase in start-up activity if reformers can construct incentives for individuals to exploit these opportunities. Reformers cannot simply design these incentives based on successes among exemplar countries without accounting for differences in the cultural and economic contexts in their respective country. Further complexity arises when policies implemented adequately within urban areas lag among significant rural populations who still follow a set of rules based on tradition and history (Ollila, 2009).

It becomes necessary to target societal legitimacy when it becomes costly for governments to provide incentives. Though the malleability of societal legitimacy is in dispute, targeting change might begin with educational investments (Autio, 2009) and practical experience (Boettke et al., 2008). Until these are in place, reformers must realize that efforts to impose institutions, whether internally- or externally-driven, will fail. Reformers could start with designing the educational system to infuse students with entrepreneurial attitudes, and to provide encouraging role models. Those with tertiary education generally face the magnitude of opportunity costs that motivate one to target high growth enterprises that are formally registered. Reformers must therefore promote entrepreneurial content in higher educational institutions. In addition, reformers could promote the sharing of experiences for established entrepreneurs and aspiring ones (Autio, 2009). Such efforts ought to bear fruits over the long term.

Reformers might start by identifying particular indigenous traditions that are in synergy with property rights, trade, and individual liberty (Boettke et al., 2008) that they can leverage 
within their policy design. The multidisciplinary nature of entrepreneurship exists even at a macro level. This calls for the requisite multidisciplinary policy approach. Thus, the design of formal operations should prioritize the alignment of diverse formal departments to the national goal of entrepreneurship development.

\subsection{Limitations and future research}

One cannot adequately cover all of the nuances of vast topics such as institutions, economic development, and entrepreneurship. Nonetheless, this research has sought to provide some basic insights into the mechanism and conditions in which formal incentives influence national start-up activity, which the majority of researchers have steered clear off until recently. Several limitations of our study provide opportunities for future research.

This study is limited to entrepreneurship in the formal private sector: we used data of formally registered new firms per country. We recommend that our research be replicated with data recognizing both formal and informal sector start-up activity.

Our data were limited to 238 country-year observations. We also used lagged variables to control for endogeneity and the time taken for the context to influence individual level behavior, further reducing our data to 155 country-year observations. Large sampling frameworks of country level data are hard to come by. We suggest that our research be replicated as sampling frameworks increase their country level data. We used GEM data for our institutional measures. The World Bank has a larger data set of institutional variables, but research might still be limited by start-up activity data. In particular, future research should target a larger sample of less-developed countries.

The GEM EFC data are based on impressions of experts, rather than "hard" data (Levie \& Autio, 2008). These experts might have an ideal of entrepreneurs based on several values and attitudes, but those values may not be determinants of startup activity in some regions (Alvarez, Urbano, Coduras, \& Ruiz-Navarro, 2011). For this reason, it might be that though some of the GEM EFCs did not lend empirical support to conditions for start- up activity, others like the World Bank's Doing Business data might do. Aside from replicating our work with other datasets, future research might consider multilevel methods that analyze for both individual and country level responses. Recent work by De Clercq et al. (2011), and Autio and Acs (2010) provide exemplars of multilevel methods applied to entrepreneurship research.

Different types of effects - substitution or complementary - might exist when one considers only particular components of formal or informal institutions. This requires careful modelling. However, one should balance this against the need for a parsimonious model. Future research could apply structural equation modelling to analyze for a more comprehensive range of interplay and endogeneity.

Further nuances arise when one considers the origins of certain institutions. Institutions can be created indigenously by national governments or by outsiders when they are foreign-introduced. Foreign institutions tend to be constructed and imposed in a top-down manner. Foreign institutions are those we typically associate with development community policy. These may be creations of foreign governments or other formal authorities like the IMF, USAID, or the World Bank (Boettke et al., 2008).

We believe that current explanations of cross-country start-up activity omit variations due to either one of formal institutions, informal institutions, or economic development. These gaps continue to exist because of the complex causality and nonlinear relationships between institutions, economic development, and start-up activity. Clearly, there is a room for future research to delve into this complexity. Cognitive dissonance theory might be helpful in this regard. The theory of cognitive dissonance centres on the idea that if an individual realizes that things are not psychologically consistent with one another, he will, in a variety of ways, try to make them more consistent (Festinger, 1957). Cognitive dissonance might arise in individuals facing conflicting incentives. Our research suggests the importance of analyzing the joint effects of formal and informal institutions to detect the cognitive dissonance between incentives and the legitimacy of starting a business. 


\section{CONCLUSION}

Our research contributes to existing knowledge about national start-up activity by showing both the mechanism and conditions for formal incentives to increase start-up activity. We have shown that the formal incentives, designed by governments, influence national start-up activity in an indirect manner through the variations in opportunities and resources made available through technological advancement or economic development. This is in line with arguments that economic development results from the adoption of particular institutions and not entrepreneurship, which is an "omnipresent aspect of human action" (Boettke \& Coyne, 2003, p. 67). Moreover, we show that this indirect effect of formal incentives becomes particularly important under conditions of low societal legitimacy for entrepreneurship. Essentially, formal incentives serve as a substitute for lower levels of societal legitimacy.

\section{REFERENCES}

1. Acemoglu, D., \& Johnson, S. (2005). Unbundling Institutions. Journal of Political Economy, 113(5). Retrieved from https://ideas.repec. org/p/nbr/nberwo/9934.html

2. Acs, Z. J., \& Szerb, L. (2010). The Global Entrepreneurship and Development Index (GEDI) (pp. 16-18). Retrieved from https:// www.researchgate.net/publication/228684521_The_Global_Entrepreneurship_and_Development_Index_GEDI

3. Acs, Z. J., \& Virgill, N. (2010). Entrepreneurship in Developing Country. Handbook of Entrepreneurship Research, 485515. Retrieved from https:// www.researchgate.net/publication/227005219_Entrepreneurship_in_Developing_Countries

4. Acs, Z. J., Desai, S., \& Hessels, J. (2008a). Entrepreneurship, Economic Development and Institutions. Small Business Economics, 31(3), 219-234. Retrieved from https://link. springer.com/article/10.1007/ s11187-008-9135-9

5. Acs, Z. J., Desai, S., \& Klapper, L. F. (2008b). What does 'entrepreneurship' Data Really Show? Small Business Economics, 31(3), 265-281. Retrieved from https://link.springer.com/article/10.1007/s11187-008-9137-7

6. Acs, Z., \& Armington, C. (2004). Employment Growth and Entrepreneurial Activity in Cities. Regional Studies, 38(8), 911-927. https://doi.org/10.1080/003434004 2000280938
7. Aidis, R., Estrin, S., \& Mickiewicz, T. M. (2012). Size Matters: Entrepreneurial Entry and Government. Small Business Economics, 39(1), 119-139. Retrieved from https://link. springer.com/article/10.1007/ s11187-010-9299-y

8. Allison, P. D. (2012). Logistic Regression Using SAS: Theory and Application. SAS Institute.

9. Alvarez, C., Urbano, D., Coduras, A., \& Ruiz-Navarro, J. (2011). Environmental Conditions and Entrepreneurial Activity: A Regional Comparison in Spain. Journal of Small Business and Enterprise Development, 18(1), 120-140. https://doi. org/10.1108/14626001111106460

10. Anokhin, S., \& Wincent, J. (2012). Start-up rates and innovation: A cross-country examination. Journal of International Business Studies, 43(1), 41-60. Retrieved from https://link.springer.com/ article/10.1057/jibs.2011.47

11. Audretsch, D., \& Keilbach, M. (2004). Entrepreneurship Capital and Economic Performance. Regional studies, 38(8), 949-959. https://doi.org/10.1080/003434004 2000280956

12. Autio, E., \& Acs, Z. (2010). Intellectual Property Protection and the Formation of Entrepreneurial Growth Aspirations. Strategic Entrepreneurship Journal, 4(3), 234-251. https://doi.org/10.1002/ sej.93
13. Baron, R. M., \& Kenny, D. A. (1986). The Moderatormediator Variable Distinction in Social Psychological Research: Conceptual, Strategic, and Statistical Considerations. Journal of personality and social psychology, 51(6), 1173-1182. Retrieved from https://www.ncbi.nlm.nih.gov/ pubmed/3806354

14. Blau, D. M. (1987). A Time-series Analysis of Self-Employment in the United Statess. The Journal of Political Economy, 95(3), 445-467. Retrieved from https://www.jstor. org/stable/1831972?seq=1\#page_ scan_tab_contents

15. Boettke, P. J., \& Coyne, C. J. (2003). Entrepreneurship and Development: Cause or Consequence? Advances in Austrian Economics, 6, 67-87. Retrieved from https://papers.ssrn. com/sol3/papers.cfm?abstract_ $\mathrm{id}=869770$

16. Boettke, P. J., Coyne, C. J., \& Leeson, P. T. (2008). Institutional Stickiness and the New Development Economics. American Journal of Economics and Sociology, 67(2), 331-358. https://doi.org/10.1111/j.15367150.2008.00573.x

17. Bowen, H. P., \& De Clercq, D. (2008). Institutional Context and the Allocation of Entrepreneurial Effort. Journal of International Business Studies, 39(4), 747-767. Retrieved from https://www.jstor. org/stable $/ 25483297$ ? seq=1\#page scan_tab_contents 
18. Busenitz, L. W., Gomez, C., \& Spencer, J. W. (2000). Country institutional profiles: Unlocking Entrepreneurial Phenomena. Academy of Management Journal, 43(5), 994-1003. https://doi. org/10.2307/1556423

19. Ciccone, A., \& Matsuyama, K. (1996). Start-up Costs and Pecuniary Externalities as Barriers to Economic Development. Journal of Development Economics, 49(1), 33-59. https://doi.org/10.1016/03043878(95)00052-6

20. Cohen, J., Cohen, P., West, S., \& Aiken, L. (2003). Applied multiple regression/correlation analysis for the behavioural behavioral sciences (3rd ed.). Mahwah, N.J.: L. Erlbaum Associates. Retrieved from https://www.amazon. com/Multiple-RegressionCorrelation-Analysis-Behavioral/ $\mathrm{dp} / 0805822232$

21. Dawson, J., \& Richter, A. (2006). Probing three-way interactions in moderated multiple regression: development and application of a slope difference test. The Journal of applied psychology, 91(4), 917926. https://doi.org/10.1037/00219010.91.4.917

22. De Clercq, D., Lim, D. S. K., \& Oh, C. H. (2011). Individual-Level Resources and New Business Activity: The Contingent Role of Institutional Context. Entrepreneurship Theory and Practice, 37(2), 303-330. https://doi.org/10.1111/j.15406520.2011.00470.x

23. De Soto, H. (2003). Mystery of Capital: Why Capitalism Triumphs in the West and Fails Everywhere Else. Basic books.

24. Djankov, S., La Porta, R., Lopez de Silanes, F., \& Shleifer, A. (2002). The Regulation of Entry. Quarterly Journal of Economics, 117(1), 1-37. https://doi.org/10.3386/w7892

25. Eckhardt, J. T. (2003). Industry Differences in Entrepreneurial Opportunities. US: University of Maryland.

26. Edwards, J. R., \& Lambert, L. S. (2007). Methods for Integrating Moderation and Mediation: a General Analytical Framework
Using Moderated Path Analysis. Psychological methods, 12(1), 1-22. https://doi.org/10.1037/1082989X.12.1.1

27. Etzioni, A. (1987). Entrepreneurship, Adaptation and Legitimation: Aa Macrobehavioral Perspective. Journal of Economic Behavior \& Organization, 8(2), 175-189. http://dx.doi.org/10.1016/01672681(87)90002-3

28. Festinger, L. (1957). A Theory of Cognitive Dissonance. Stanford University Press.

29. Gries, T., \& Naudé, W. (2009). Entrepreneurship and Regional Economic Growth: Towards a General Theory of Start-ups. Innovation - The European Journal of Social Science Research, 22(3), 309-328. https://doi. org/10.1080/13511610903354877

30. Gwartney, J. D., Lawson, R. A., \& Holcombe, R. G. (1999). Economic Freedom and the Environment for Economic Growth. Journal of Institutional and Theoretical Economics, 155(4), 643-663. Retrieved from https://www.jstor.org/ stable $/ 40752161$ ?seq=1\#page scan_tab_contents

31. Iakovleva, T., Kolvereid, L., \& Stephan, U. (2011). Entrepreneurial intentions in developing and developed countries. Education + Training, 53(5), 353-370. https://doi. org/10.1108/00400911111147686

32. Jackson, L. F. (1984). Hierarchic Demand and the Engel Curve for Variety. The Review of Economics and Statistics, 66(1), 8-15. https:// doi.org/10.2307/1924690

33. Kirzner, I. M. (1973). Competition and entrepreneurship. Chicago: University of Chicago Press.

34. Klapper, L., \& Delgado, J. (2007). World Bank Group Entrepreneurship Survey: Data Overview.

35. Klapper, L., Laeven, L., \& Rajan, R. (2006). Entry Regulation as a Barrier to Entrepreneurship. Journal of Financial Economics, 82(3), 591-629. https://doi. org/10.1016/j.jfineco.2005.09.006
36. Levie, J., \& Autio, E. (2008). A Theoretical Grounding and Test of the GEM Model. Small Business Economics, 31(3), 235263. Retrieved from https://link. springer.com/article/10.1007/ s11187-008-9136-8

37. Levie, J., \& Autio, E. (2011). Regulatory Burden, Rule of Law, and Entry of Strategic Entrepreneurs: An International Panel Study. Journal of Management Studies, 48(6), 1392 1419. https://doi.org/10.1111/ j.1467-6486.2010.01006.x

38. Liñán, F., \& Chen, Y. W. (2009). Development and Cross-Cultural application of a specific instrument to measure entrepreneurial intentions. Entrepreneurship Theory and Practice, 33(3), 593-617. https://doi.org/10.1111/j.15406520.2009.00318.x

39. Meek, W. R., Pacheco, D. F., \& York, J. G. (2010). The Impact of Social Norms on Entrepreneurial Action: Evidence from the Environmental Entrepreneurship Context. Journal of Business Venturing, 25(5), 493-509. https://doi.org/10.1016/j.jbusvent.2009.09.007

40. Moran, P., \& Ghoshal, S. (1999). Markets, Firms, and the Process of Economic Development. Academy of Management Review, 24(3), 390-412. https://doi. org/10.2307/259133

41. Muller, D., Judd, C. M., \& Yzerbyt, V. Y. (2005). When Moderation Is Mediated and Mediation Is Moderated. Journal of personality and social psychology, 89(6), 852863. https://doi.org/10.1037/00223514.89.6.852

42. North, D. C. (1990). Institutions, Institutional Change and Economic Performance. Cambridge university press.

43. O'Brien, R. M. (2007). A Caution Regarding Rules of Thumb for Variance Inflation Factors. Quality \& Quantity, 41(5), 673690. Retrieved from https://link. springer.com/article/10.1007/ s11135-006-9018-6

44. Ollila, P. (2009). Principles of Institutional Economics 
(Marketing, Working Papers

(56)). Retrieved from https://www. coursehero.com/file/22504278/ Principles-of-institutional-economics/

45. Ostrom, E. (2009). Understanding institutional diversity. Princeton University Press.

46. Ozawa, T. (1992). Foreign Direct Investment and Economic Development. Transnational Corporations, 1(1), 27-54.

47. Porter, M. E., Sachs, J., \& McArthur, J. W. (2002). Executive summary: Competitiveness and stages of economic development. In The global competitiveness report 2001-2002. New York, Oxford (UK): Oxford University Press.

48. Reynolds, P, Storey, D. J., \& Westhead, P. (1994). Crossnational Comparisons of the Variation in New Firm Formation Rates. Regional Studies, 28(4), 443456. https://doi.org/10.1080/00343 409412331348386

49. Rodrik, D., Subramanian, A., \& Trebbi, F. (2004). Institutions Rule: The Primacy of Institutions over Geography and Integration in Economic Development. Journal of economic growth, 9(2), 131-165. https://doi.org/10.3386/w9305

50. Saville, D. J., \& Wood, G. R. (1991). Statistical Methods: The Geometric Approach. Springer New York.

51. Scott, W. R. (1994). Institutions and Organizations: Toward a Theoretical Synthesis. Sage, Thousand Oaks, CA.

52. Scully, G. W. (1988). The Institutional Framework and Economic Development. The Journal of Political Economy, 96(3), 652-662. Retrieved from https://www.jstor.org/ stable/1830363?seq=1\#page_scan_ tab_contents

53. Shane, S. (2003). A General Theory of Entrepreneurship: The Individual-opportunity Nexus. Edward Elgar Pub.

54. Shane, S., \& Venkataraman, S. (2000). The Promise of Entrepreneurship as a Field of
Research. Academy of management review, 25(1), 217-226. https://doi. org/10.2307/259271

55. Shleifer, A. (2009). The Age of Milton Friedman. Journal of Economic Literature, 47(1), 123-135. Retrieved from https:// scholar.harvard.edu/shleifer/publications/age-milton-friedman

56. Solow, R. M. (1957). Technical Change and the Aggregate Production Function. The review of Economics and Statistics, 39(3), 312-320. http://dx.doi. org/10.2307/1926047

57. Stenholm, P., Acs, Z. J., \& Wuebker, R. (2011). Exploring Countrylevel Institutional Arrangements on the Rate and Type of Entrepreneurial Activity. Journal of Business Venturing, 28(1), 176193. https://doi.org/10.1016/j. jbusvent.2011.11.002

58. Tang, L., \& Koveos, P. (2004). Venture entrepreneurship, innovation entrepreneurship and economic growth. Journal of Developmental Entrepreneurship, 9(2), 161-171. Retrieved from https://www.researchgate.net/ publication/256004173_Venture_Entrepreneurship_Innovation_Entrepreneurship_and_Economic Growth

59. Van Stel, A., Carree, M., \& Thurik, R. (2005). The Effect of Entrepreneurial Activity on National Economic Growth. Small Business Economics, 24(3), 311-321. Retrieved from https://www.jstor.org/ stable/40229425? seq=1\#page_ scan_tab_contents

60. Webb, J. W., Tihanyi, L., Ireland, R., \& Sirmon, D. (2009). You say illegal, I say legitimate: Entrepreneurship in the informal economy. Academy of Management Review, 34(3), 492-510. https://doi.org/10.5465/ AMR.2009.40632826

61. Weingast, B. R. (1995). Economic Role of Political Institutions: Market-Preserving Federalism and Economic Development. Journal of Law, Economics, \& Organization, 11(1), 1-31. Retrieved from https://www.jstor. org $/$ stable $/ 765068$ ? seq=1\#page scan_tab_contents
62. Wennekers, S. van Wennekers, A., Thurik, R., \& Reynolds, P. (2005). Nascent Entrepreneurship and the Level of Economic Development. Small Business Economics, 24(3), 293-309. Retrieved from https:// link.springer.com/article/10.1007/ s11187-005-1994-8

63. Wennekers, S., \& Thurik, R. (1999). Linking Entrepreneurship and Economic Growth. Small business economics, 13(1), 27-56. Retrieved from https://link.springer.com/article/10.1023/A:1008063200484

64. Williamson, O. E. (2000). The New Institutional Economics: Taking Stock, Looking Ahead. Journal of economic literature, 38(3), 595-613. Retrieved from https://www.jstor. org/stable/2565421?seq=1\#page_ scan tab_contents

65. Xu, C. (2011). The Fundamental Institutions of China's Reforms and Development. Journal of Economic Literature, 49(4), 1076-1151. Retrieved from https://www.jstor.org/ stable/23071664?seq=1\#page _ scan tab_contents

66. Young, S., Hood, N., \& Peters, E. (1994). Multinational Enterprises and Regional Economic Development. Regional Studies, 28(7), 657-677. https://doi.org/10. 1080/00343409412331348566 